Corrigendum

\title{
Corrigendum to "In Vitro Evaluation of Probiotic Properties of Lactic Acid Bacteria Isolated from Some Traditionally Fermented Ethiopian Food Products"
}

\author{
Guesh Mulaw $\mathbb{D}^{1},{ }^{1,2}$ Tesfaye Sisay Tessema, ${ }^{3}$ Diriba Muleta ${ }^{\mathbb{D}},{ }^{3}$ and Anteneh Tesfaye ${ }^{3}$ \\ ${ }^{1}$ Department of Microbial, Cellular and Molecular Biology, College of Natural and Computational Sciences, \\ Addis Ababa University, Addis Ababa 1176, Ethiopia \\ ${ }^{2}$ Department of Biology, College of Natural and Computational Sciences, Aksum University, Axum 1010, Ethiopia \\ ${ }^{3}$ Institute of Biotechnology, College of Natural and Computational Sciences, Addis Ababa University, Addis Ababa 1176, Ethiopia \\ Correspondence should be addressed to Guesh Mulaw; guesh2001@gmail.com
}

Received 20 April 2020; Accepted 28 May 2020; Published 30 July 2020

Copyright $\odot 2020$ Guesh Mulaw et al. This is an open access article distributed under the Creative Commons Attribution License, which permits unrestricted use, distribution, and reproduction in any medium, provided the original work is properly cited.

In the article titled "In Vitro Evaluation of Probiotic Properties of Lactic Acid Bacteria Isolated from Some Traditionally Fermented Ethiopian Food Products" [1], the headings for Sections 3.3.4 and 3.3.5 were reversed. The correct headings are as follows:

3.3.4. Bacterial Adhesion to Stainless Steel Plates

3.3.5. Antibiotic Susceptibility Test

\section{References}

[1] G. Mulaw, T. Sisay Tessema, D. Muleta, and A. Tesfaye, "In vitro evaluation of probiotic properties of lactic acid bacteria isolated from some traditionally fermented Ethiopian food products," International Journal of Microbiology, vol. 2019, Article ID 7179514, 11 pages, 2019. 